\title{
Comparison of Politeness Principles in Ustaz Khalid Basalamah Lecture with Ustaz Zulkifli Muhammad Lecture
}

\author{
Ermanto $^{1, *}$ David Syasli ${ }^{2}$ Novia Juita ${ }^{1}$
}

\author{
${ }^{1}$ Indonesian Literature Program Study, Universitas Negeri Padang, Padang, Indonesia \\ ${ }^{2}$ SMPN 4 Batipuh. West Sumatra, Indonesia \\ *Corresponding author. Email: ermanto@fbs.unp.ac.id
}

\begin{abstract}
This study presents a comparison of the principles of politeness in the communication of Ustaz Khalid Basalamah's lectures with Ustaz Zulkifli Muhammad Ali's lectures. The data used is in the form of speech delivered by Ustaz Khalid Basalamah and Ustaz Zulkifli Muhammad Ali in da'wah/lectures. The data source was obtained from video lectures of Ustaz Khalid Basalamah and Ustaz Zulkifli Muhammad Ali which were downloaded from the internet/youtube. In collecting data, the researcher used the listening technique. The listening technique is carried out using the free-of-conversation listening technique, the recording technique, and the note-taking technique. Analysis of the data using analysis according to Miles and Huberman. Data gathering, data extraction, data display, and making conclusions are all part of the analysis. Data analysis was performed after the video was transcribed. The data analysis technique consists of four steps. First, data identification, i.e. data that has been transcribed is read again and again, then marks and names the data according to the speech form of the politeness principle. Second, classifying research data, after the data is identified. Then classified based on the form of the principle of politeness. Third, interpreting the data, that is, the meaning of the speech is interpreted and explained based on the politeness principle. Fourth, make conclusions about the data that has been analyzed. Based on the results of data analysis, this study found that the politeness principle of Ustaz Khalid Basalamah was dominated by tact maxims (33\%) and humility maxims 27 utterances (27\%), while the politeness maxims of Ustazah Zulkifli Muhammad Ali were dominated by tact maxims 13 utterances $(26 \%)$ and the maxim of praise as many as 13 utterances $(26 \%)$. The similarity of politeness principles in Ustaz Khalid Basalamah's speech with Ustaz Zulkifli Muhammad Ali is that they both try to present polite speech and show that they have power in lecturing. The difference between Ustaz Khalid Basalamah's speech and Ustaz Zulkifli Muhammad Ali's speech is that Ustaz Khalid Basalamah's speech acts still show respect and care for the feelings of his congregation, while Ustaz Zulkifli Muhammad Ali's speech acts show more respect or praise for his congregation to deliver lectures or da'wah.
\end{abstract}

Keywords: comparative, politeness, ustaz.

\section{INTRODUCTION}

Bahasa Language is used as a medium in the delivery of communication so that the function and purpose of the conversation will take place well. One media dal am communicating is a lecture or da kwah given by preachers or Ustazah. The use of language will have an influence on the listener both in one's thoughts and behavior. Each speaker or preacher conveys a message, purpose, and its own characteristics, all of which are wrapped by politeness and effectiveness in speaking. Hendrikus [1] says that in order to achieve success in preaching, the lecturer will pay attention to several things, namely the determination of speech, placement of stress, tone, duration, attitude, voice, mastery of topics and language. Badrudin et al [2] said 
the same thing, he revealed that in order for da'wah to be understood and accepted by the community, da'wah must use effective, communicative, and persuasive language. In addition, polite language is also one of the important things in preaching.

Language politeness is the way a person speaks and behaves towards the speech partner with the values contained in society. According to Brown and Levinson [3], politeness is related to the concept of self-image (face) refers to the characteristics of positive and negative self-image. Grice [4] also states that polite language is a language that pays attention to the dignity of the speech partner so as not to feel humiliated, must not say unkind things about the speech partner, must not express pleasure over the speech partner's misfortune, must not express disapproval., and should not praise yourself According to Leech [5], language politeness is an attempt to limit the occurrence of impolite thoughts and ideas by adhering to the principle of language politeness, which is made up of maxims.

Furthermore, Yule [6] defines politeness as an instrument for demonstrating awareness of other someones face. This face is a person's personal form in society which will refer to the social and emotional meanings that each person has and wants others to know or understand about it. Furthermore, Room [7] defines politeness as a result of social processes and sociocultural development that is not innate. Speaking politely and politely can also foster a person's sympathy for the speaker and contains a high value of respect for the speaker, Budiwati [8].

In line with this, Leech [5] said that in interacting it is necessary to consider and apply the principle of courtesy or politeness. The principle of politeness in this study uses Leech's theory. Leech [5] describes the principle of politeness into six maxims (stipulations, teachings). First, the Tact Maxim means making the damage of others as small as possible while increasing the benefit to others as much as possible. Second, the maxim of generosity, make your own profit as small as possible and make your own loss as big as possible. Third, the maxim of praise, criticize others as little as possible and praise others as much as possible. Fourth, the Modesty Maxim, praise yourself as little as possible and criticize yourself as much as possible. Fifth, the maxim of agreement, try to make the inequality between self and other happen as little as possible, and try to make the agreement between self and other happen as much as possible. Sixth, the maxim of sympathy, reduce the feeling of antipathy between self and others to the smallest possible extent, and increase sympathy as much as possible between self and others.
Politeness in the form of speech or language politeness is not only a controlling component that maintains it correct, enjoyable, and not in vain, but it is also a motivator for speakers to speak [9]. Violation of politeness in language in the last decade seems to be a serious phenomenon. Research that discusses this includes in the UK (Culpeper [10]; Jansen, [11]; Rudanko [12]); in the USA (Perez [13]; Noulizavin [14]; Wacker [15]; Grebelsky [16]) and in France (Ledegaard [17]; Fracchiolla, [18]. Language in terms of religion has almost lost its value in Indonesia, according to research, because it has become a medium to curse, scold, attack, and even bring down others. This is supported by a number of research findings in Persia [19], in Japan [20], Smith [21], Dicket [22] in Turkey [23], and in Italy [24].

Furthermore, research conducted by Hermansyah \& Supriadi [25]. This study examines the style of communication and da'wah carried out by Ustadz Yusuf Mansyur. From the research conducted, the form of communication carried out by Ustadz Yusuf Mansyur in conveying da'wah verbally is to use descriptive, persuasive language, and also insert humor with an introduction to Indonesian with a Betawi-Javanese accent. The form of communication approach used by Ustadz Yusuf Mansyur is fiqh of worship and shodaqoh, economics, and testimony. Furthermore, research conducted by Wahyuni [26]. This study examines the politeness of speaking Indonesian preaching by Ustadz Nur Maulana. From the results of the research conducted, speakers can be said to be polite because the number of utterances that obey the maxims is greater than the amount of data that violates them. From several studies that have been described, this research has a relationship in the form of a study of language politeness with the research.

Based on the several studies presented, it is concluded that the study of language politeness towards the speech of the ustaz's lectures or da'wah has not been widely carried out. This research is certainly different from previous research because this study will examine language politeness in conveying da'wah. The focus of this study is to compare the principles of politeness in Ustaz Khalid Basaamah's lecture with Ustaz Zulkifli Muhammad Ali's lecture as a well-known Islamic religious figure in Indonesia. The researcher chose Ustaz Khalid Basaamah's lecture with Ustaz Zulkifli Muhammad Ali's lecture as the object of research because the two clerics were clerics who were much favored by the congregation. 


\section{METHOD}

This study is qualitative in nature. Qualitative research is defined as a social science research method that collects and analyzes data in the form of words (oral or written) and human actions and the researcher does not calculate or quantify the qualitative data that has been obtained and thus analyze the numbers, Afrizal [27]. Mahsun [28] explained that qualitative research is data that is analyzed in the form of words, not in the form of numerical data (qualitative data). Furthermore, Gunawan [29] revealed that the qualitative approach emphasizes the analysis of inductive thinking processes related to the dynamics of the relationship between observed phenomena and uses scientific logic.

The research method employed is descriptive qualitative research. This method (as contrary to experiments) is used to investigate the condition of natural objects, with the researcher serving as the primary instrument. Also, the triangulation technique is used to collect data, inductive data analysis is used, and qualitative research findings highlighting meaning instead of generalization [30]. The subject of this research is the politeness of language used by Ustaz Khalid Basalamah and Ustaz Zulkifli Muhammad Ali in their lectures on YouTube. The study used the object of politeness maxim used by Ustaz Khalid Basalamah and Ustaz Zulkifli Muhammad Ali. The data used is in the form of speech delivered by Ustaz Khalid Basalamah and Ustaz Zulkifli Muhammad Ali in da'wah/lectures. The utterance includes six maxims of politeness in language. The data source was obtained from video lectures of Ustaz Khalid Basalamah and Ustaz Zulkifli Muhammad Ali which were downloaded from the internet/youtube.

The research instrument is the researcher himself (human instrument) assisted by several video lectures, earphones, and a laptop because the position of the researcher in this study is as a planner, executor of data collection, analyst, data interpreter and ultimately reporting the results of the research itself. In collecting data, the researcher used the listening technique. The listening technique is carried out using the free-ofconversation listening technique, the recording technique, and the note-taking technique. This is done so that the data obtained is clear and accurate. The researcher listened to the lectures of Ustaz Khalid Basalamah and Ustaz Zulkifli Muhammad Ali first. Then the video is transcribed into written form. Furthermore, the data is classified based on the maxim of politeness in language.
Analysis of the data using analysis according to Miles and Huberman [31]. Data gathering, data extraction, data display, and making conclusions are all part of the analysis. Data analysis was performed after the video was transcribed. The data analysis technique consists of four steps. First, data identification, i.e. data that has been transcribed is read again and again, then marks and names the data according to the speech form of the politeness principle. Second, classifying research data, after the data is identified. Then classified based on the form of the principle of politeness. Third, interpreting the data, that is, the meaning of the speech is interpreted and explained based on the politeness principle. Fourth, make conclusions about the data that has been analyzed This data analysis is presented using a descriptive method, namely by constructing the data in the form of sentences rather than statistics.

\section{RESULTS and DISCUSSION}

This study obtained the results of the comparison of the use of the principle of politeness in Ustaz Khalid Basalamah's lecture with Ustazah Zulkifli Muhammad Ali's lecture. The comparison of the use of politeness principles in the ustaz's lecture is shown in the table below.

Table 1. Comparison of the Polite Principles of Ustaz Khalid Basalamah with Ustaz Zulkifli Muhammad Ali
\begin{tabular}{|c|l|c|c|c|c|}
\hline No. & \multicolumn{1}{|c|}{ Courtesy Principle } & Ustaz Khalid Basalamah & Ustaz Zulkilli Muhammad Ali \\
\hline 1 & Tact Maxim & 33 & $33 \%$ & 13 & $26 \%$ \\
\hline 2 & Generosity Maxim & 9 & $9 \%$ & 8 & $16 \%$ \\
\hline 3 & ApprobationMaxim & 13 & $13 \%$ & 13 & $26 \%$ \\
\hline 4 & Modesty Maxim & 18 & $18 \%$ & 4 & $8 \%$ \\
\hline 5 & AgreementMaxim & 11 & $11 \%$ & 9 & $18 \%$ \\
\hline 6 & Sympathy Maxim & 16 & $16 \%$ & 3 & $6 \%$ \\
\hline & Total & $\mathbf{1 0 0}$ & $\mathbf{1 0 0 \%}$ & $\mathbf{5 0}$ & $\mathbf{1 0 0 \%}$ \\
\hline
\end{tabular}

Based on the data in table 1, Ustaz Khalid Basalamah's lecture obtained 100 utterances, where the tact maxim is 33 utterances $(33 \%)$, generosity maxim of is 9 utterances $(9 \%)$, approbation maxim is 13 utterances $(13 \%)$, modesty maxim is 18 utterances ( $18 \%$ ), maxim of agreement 16 utterances $(16 \%)$, maxim of sympathy 11 utterances (11\%). Meanwhile, from 50 speeches in Ustaz Zulkifli Muhammad Ali's lecture, there were 13 utterances of tact maxim (26\%), 8 utterances of generosity maxim (16\%), 13 utterances of approbation maxim $(26 \%), 4$ utterances of modesty maxim $(8 \%)$, maxim of agreement 9 utterances $(18 \%)$, maxim of sympathy 3 utterances $(6 \%)$.

\subsection{Ustaz Khalid Basalamah}

Of the 100 data analyzed, the maxims that donated in Ustaz Khalid Basalamah's lecture were tact maxims 
with 33 utterances (33\%) and humility maxims with 18 utterances $(18 \%)$. The following is an example of the principle of politeness tact maxim and Modesty Maxim in Ustaz Khalid Basalamah's speech.

\subsubsection{Tact Maxim}

The tact maxim, make the losses of others as small as possible and make the profits of others as large as possible, Leech, [5]. Based on the data findings, it was found that the tact maxim were 33 forms of speech spoken by UKB. The implementation of several tact maxim can be seen in the speech contained in the following preaching of Ustaz Khalid Basalamah.

(1) "Semoga sisa umur kita ke depan terisi dengan amal saleh. Berkah di harta, di keturunan, di pasangan dan juga di ilmu dan harta kita, serta semoga saja dimasukkan surga tanpa hisab."

(1) "May the rest of our life in the future be filled with good deeds. Blessings in wealth, in offspring, in partners and also in our knowledge and wealth, and may heaven be entered without reckoning. "

The data in speech (1) shows that there is an utterance from Ustaz Khalid Basalamah that is in accordance with the tact maxim. This is because in his speech, Ustaz Khalid Basalamah makes people's losses as small as possible and other people's profits as large as possible. This is marked by Ustaz Khalid Basalamah who prays for his listeners so that life is always filled with pious deeds and blessings always until they are entered into heaven without reckoning.

\subsubsection{Modesty Maxim}

The Modesty Maxim is an utterance that reduces or minimizes self-praise, or maximizes expressions of not praising or highlighting oneself as a speaker. Based on research, Yahdi [32], The modesty maxim in conversational speech will occur if the speaker always praises and stands out in front of the speech partner. The speech delivered in the video lecture of Ustaz Khalid Basalamah contained 18 utterances that showed the modesty maxim as shown in the following example.

(2) "Saya liat kalau saya tidak paksakan diri bangun malam, saya nggak salat malam itu. Pernah saya begitu saya cuman biasa saja tertidur udah azan Subuh keluar. Salat malam saya lewat loh dan buku amal tidak bisa diperbaikin, nggak bisa di-review"

(2) "I saw that if I didn't force myself to wake up at night, I wouldn't pray that night. Once I was like that, I just used to fall asleep when the Fajr call to prayer came out. My evening prayers are passing, and the charity book cannot be repaired, it cannot be reviewed"

From the quote of speech (2) according to the modesty maxim. Ustaz Khalid Basalamah praised himself as little as possible which was marked by me seeing if I didn't force myself to wake up at night, I didn't pray that night here Ustaz Khalid Basalamah praised himself that he still had time to pray by forcing himself and criticized himself with negligence and indecision myself in worship which is marked by my evening prayers passing tablets and the charity book cannot be repaired here UKB criticizes itself for its negligence. Furthermore, Ustaz Khalid Basalamah's speech which also includes the Modesty Maxim. This is in line with the research conducted by Febriad Ina, et all [33] that in a communication, understanding and awareness of language politeness is needed between speakers and speech partners in order to create good and smooth communication.

\subsection{Ustaz Zulkifli Muhammad Ali}

Of the 50 data analyzed, the maxims that donate in Ustaz Zulkifli Muhammad Ali's lecture are tact maxims with 13 utterances $(26 \%)$ and praise maxims as many as 13 utterances (26\%). The following is an example of politeness tact maxim and maxim of praise in the speech of Ustaz Zulkifli Muhammad Ali .

\subsubsection{Tact maxim}

Tact Maksim is one of the Leech politeness principle, which should reduce the speakers of words that cause harm to others and maximize the benefit of others in speaking, Leech [5]. Based on the speech delivered by Ustaz Zulkifli Muhamad Ali, there are 13 forms of tact maxims. One of the 13 forms of tact maxim is as follows.

(3) Mohon maaf ya pak, buk. Di Madinatul Munawarah sudah diadakan konser musik, di Madinatul Munawarah. Laki-laki dan wanita habis-habisan, para petinggi-petingginya tidak malu-malu mencekek botol-botol minumam keras kelas dunia, Madinatul Munawarah.

(3) Sorry, sir, sir. In Madinatul Munawarah, a music concert has been held, in Madinatul Munawarah. Men and women went all out, the top brass were not shy about choking bottles of world class liquor, Madinatul Munawarah .

Speech ( 3 ) shows the tact maxim from the speech delivered by Ustaz Zulkifli Muhamad Ali, because it contains the word sorry. Base of Zamzani research, et al [34], the tact maxim in a speech to avoid the attitude of envy, jealousy or any less polite attitude towards hearer. Usually the tact maxim contains the words, 
apologize, thank you, please, please, reprimand, invite and order, so as to create a polite impression on the speaker and the speech partner.

\subsubsection{Approbation Maxim}

Speech that is considered to be a approbation maxim is speech that is able to reduce expressions of condescending to other parties, and can maximize appreciation or praise of speech partners by expressing expressions in the form of praise or appreciation. Ha 1 This concurs with Rashid [35] that the politeness principle is very attentive to every speech delivered by speakers kemitra said by observing the context of the conversation. The speaker must not humiliate or embarrass the speech partner in front of the other party. There are 13 research data related to the approbation maxim conveyed by Ustaz Zulkifli Muhamad Ali, including,

(4) Orang ini Mayjen Abdul Aziz Al-Faqhor, ini adalah orang terkuat. James Bondnya abad ke20 paling pintar, jenius, loyal dengan keluarga kerajaan dan beliau telah ditembak.

(4) This person is Major General Abdul Aziz AlFaqhor, this is the strongest person. James Bond of the 20th century is smartest, genius, loyal to the royal family and he has been shot .

Speech ( 4 ) shows that the speaker praises and respects the other party in front of the speech partner. Speakers say the strongest man and James Bond of the 20th century, the smartest, genius and loyal. The sentence is a form of appreciation or praise conveyed by the speaker, by maximizing respect for the other party and reducing expressions that demean the other party in front of the interlocutor. This is in line with research conducted by Ermano, et al [36] which revealed that one of the politeness principles used by exclusive officials of West Sumatra in oral communication is the maxim of praise or appreciation.

\section{CONCLUSION}

Based on the results of data analysis and discussion, this study obtained two conclusions. First, Ustaz Khalid Basalamah dominantly used the principle of politeness tact maxim as many as 33 speeches (33\%) and the modesty maxim as many as 27 speeches (27\%) to convey da'wah to his congregation, while Ustaz Zulkifli Muhammad Ali used the principle of politeness tact maxim as many as 13 speeches $(26 \%)$ and the approbation maxim as many as 13 utterances (26\%) to convey da'wah to the congregation. To two, equality principle of modesty in speech Ustaz Khalid Basalamah by Ustaz Zulkifli Muhammad Ali are both trying to show the speech were polite and showed that power in the lecture. The difference between Ustaz Khalid Basalamah's speech and Ustaz Zulkifli Muhammad Ali 's speech is that Ustaz Khalid Basalamah's speech acts still show respect and care for the feelings of his congregation, while Ustaz Zulkifli Muhammad Ali 's speech acts show more respect or praise for his congregation to deliver lectures or da'wah.

\section{ACKNOWLEDGMENTS}

The author would like to thank the reviewers who have provided comments, suggestions, and criticism for improvements to this manuscript. Contributions made have helped improve the quality of this article.

\section{REFERENCES}

[1] Hendrikus, D. W. (1995). Retorika: Terampil Berpidato, Berdiskusi, Berargumentasi, Bernegosiasi, Yogyakarta: Kanisius.

[2] Badrudin, A., Sastra, J., Fakultas, I., Budaya, I., \& Jember, U. (2016). Diksi dan Gaya Bahasa pada Poster Dakwah Karya Muslim Designer Community di Facebook. Publika Budaya, 1 (1), 1-12.

[3] Brown, P dan S.C. Levinson. (1987). Universal in Language Usage: Politeness Fhenomena.In E.N. (ed). Questionand Politeness Strategies in Social Interaction.Cambridge: Cambridge Universitis Press.

[4] Grice, Paul. (1975). Logic Andconversation dalam Cole, Peter dan Jerry L. Morgan (Ed). Syntax and semantics valume 3: Speech Act. New York: Academic Press.

[5] Leech, G.(1993). Prinsip-prinsip Pragmatik. Jakarta: UI Press.

[6] Yule, G. (2014). Pragmatics. Oxford \& New York: Oxford University Press.

[7] Room, R.(2013). Konsep Kesantunan Berbahasa dalam Islam. Adabiyah, 13 (2), 223-234.

[8] Budiwati, T.,R. (2017). Kesantunan Berbahasa Mahasiswa dalam Berinteraksi dengan Dosen di Universitas Ahmad Dahlan: Analisis Pragmatik. The 5th Urecol Proceeding. (7): 42.

[9] Zahid, M. (2015). Kesantunan dalam Debat Indonesia Lawyers Club di TV One. Jurnal Pendidikan, 2 (3), 20-216.

[10] Culpeper, J. (2003). Impoliteness revisited: with special reference to dynamic and prosidie aspects. Journal of pragmatic, 35 (10), 12-13

[11] Jansen, F. (2004). Efreits of positive politeness 
strategy in business letters. Journal of pragmatic, 36 (11), 6-7.

[12] Rudanko, J. (2006). Aggravated impoliteness and two types of speaker intention in an episode in shakespear as timon of Athens. Journal of pragmatic, 38, 20-24.

[13] Perez, S, FTA and Erskine May. (2003). conflicting needs? Politenes in question time. Journal pragamatic, 35 (10), 9-10.

[14] Noulizavin, P. (2011). Rong in political television debates. Journal of pragmatic, 43 (2), 35-36.

[15] Wacker, M. (2011). That is your evidence? Classifying stance in online political debate. Journal pragmatic, 10 (13), 12-16.

[16] Grebelsky, T. (2014). The role of verbal and nonverbal behaviuor Televised political debates. journal published online, 10 (15), 16-17.

[17] Ladegaard, H. (2004). Politeness in young childrens speech: context peer group influence and pragmatics competence. Journal of pragmatic, 36 (11), 19-20.

[18] Fracchiola, B. (2011). Politeness as a strategy of attack in a gendered political debate-the royalsarkozy debate. Journal of pragmatic, 10 (2).

[19] Solemmanni, H. (2016). An analysis of pragmatics competence in 2013 presidential election candidates of Iran: a comparison of speech acts with the peel outcomes. Journal academy publication, 6 (4), 12-15.

[20] Bravo, D. (2008). Politenessin Spanish speaking Socio-Cultural contexts: introductions. Journal pragmatic associations, 18 (4), 8-9.

[21] A. S Smith, S. (2011). Honorifics Politeness an power in Japaness political. Journal pragmatic, $10,(6), 12-16$.

[22] Dicket, C. (2011). Formal forms er verbal strategis? Politeness theory and Japaness business etiquette training. Journal pragmatic, 10 (10), 5-6.

[23] Yerhin, N. (2015). A pragmatics analysis of derogration in the discourse of political criticism in the Turkish grand national assembly. Journal faculty, 2 (10), 35-36.

[24] Joseph, C. (2014). The use of demonstrative and context activation in catalan parliamentary debate. Journal pragmatic, 10 (16), 27-28.

[25] A. Hermansyah, \& Supriadi, W. (2017). Komunikasi dan Dakwah Ustadz Yusuf Mansyur. Jurnal El-Hikmah, IX (2), 2-17.

[26] Wahyuni, W. (2018). Analisis Maksim Kesantunan Berbahasa Indonesia Dakwah Ustaz Nur Maulana Melalui Trans TV. Skripsi. FBS: Universitas Negerei Makassar.
[27] Afrizal. (2015). Metode Penelitian Kualitatif. Jakarta: Raja Grafindo Persada.

[28] Mahsun. 2013. Metode Penelitiam Bahasa: Tahapan, Strategi, Metode, dan Tekniknya. Jakarta: Rajagrafindo Persada.

[29] Gunawan, I. (2017). Metode Penelitian Kualitatif. Jakarta: Bumi Aksara.

[30] Sugiyono. (2010). Metode Penelitian Pendidikan, Pendekatan Kuantitatif, Kualitatif dan R \& B. Bandung: Alfabeta.

[31] Miles, M.B \& Huberman, A.M, (1994). Qualitative data analysis, 2nd ed. USA: Sage Publication.

[32] Yahdi, A., Juita, N. \& Nngusman. (2012). Kesantunan Berbahasa Mandailing dalam Tindak Tutur Direktif Anak Kepada Orang Tuanya di Nagari Ujung Gading Kecamatan Lembah Melintang Kabupaten Pasaman. Jurnal Pendidikan Bahasa dan Sastra Indonesia, 1 (1), 87-166.

[33] Febriadina, F. Z., Sumarwati, Sumarlam. (2018). Kesantunan Siswa Laki-Laki dan Perempuan di Sragen Jawa Tengah. Jurnal Humanus, 17 (1), 73-83.

[34] Zamzani, Z. (2011). Pengembangan Alat Ukur Kesantunan Bahasa Indonesia dalam Interaksi Sosial Bersemuka. LITERA,10 (1).

[35] Rashid, A.R., Ismail, R.I., Ismail, R.,\& Mamat, R. (2017). Ketidaksantunan dalam Perbualan Bahasa Jepun oleh Pemandu Pelancong Malaysia. Jurnal Gema Online, 17 (3), 87-105.

[35] Ermanto, Agustina, Emidar, Performa Bahasa dan Kesantunan Komunikasi Lisan Pejabat Sumatera Barat. Padang, 2017. 